\title{
OBIECTELE DE OS DIN AȘEZAREA MEDIEVALĂ DE LA ŞIBOT (CÂMPUl PÂINII)
}

ANDRA SAMSON

\section{REZUMAT:}

Situl medieval de la Șibot (Câmpul Pâinii) a fost fost cercetat în anul 2012, prin lucrări de cercetare arheologică preventivă. Zona de pe valea Mureșului, bogată în materiale arheologice, a confirmat prezența unui sat medieval, distrus la sfârșitul secolului al XV-lea, în timpul bătăliei de la Câmpul Pâinii (13 octombrie 1479). Cercetarea arheologică a confirmat prezenţa potenţialului arheologic, fiind identificate şi investigate exhaustiv 300 de complexe arheologice.

Demersul de față prezintă rezultatele analizei obiectelor din os descoperite pe suprafața sitului. Artefactele analizate provin din complexele de locuire ale sitului, fiind vorba de obiecte de uz casnic (într-un singur caz este vorba de plăseaua unui cuțit de luptă), un total de 23 obiecte. Din totalul artefactelor vorbim despre patru pieptăni din os, cinci ace de cusut (din care unul încă la stadiul de prelucrare), trei nasturi (sau fragmente de nasturi), șase plăsele de os/corn (sunt de la cuțiele de bucătărie, unul singur fiind de la un cuțit de luptă), patru aplice (de diferite forme), și un obiect din corn ce servea drept cuier/agăţătoare.

\section{Abstract: Bone ARTifacts From the Medieval SeTtlement of Şibot (CÂmpul PÂIniI)}

The medieval settlement in Șibot (Câmpul Pâinii) was investigated in 2012. The zone, rich from archaeological materials, confirmed the presence of a medieval settlement of the 15th century, destroyed during the battle of October 13, 1479 (the battle of Câmpul Pâinii). Throughout an open area archaeological excavation it was fully investigated 300 archaeological complexes.

The article presents the bone artifacts found on site. The objects are coming from the dwellings of the 15 th century in the case of household objects (one of them is from a battle knife), in total 23 artifacts. There are four bone combs, five sewing needles (one of which is still being processed), three buttons, six bone/antler hilts (they are from kitchen knives, only one is being from a battle knife), four appliqués of different shapes and antler object which served as a hanger.

CUVINTE CHEIE: Șibot, pieptăn din os, ac de cusut, nasture, plăsea, cuțit de luptă, aplică

KEYWORDS: Șibot, bone comb, sewing needle, button, hilt, battle knife, appliqué

Situl medieval de la Șibot (Câmpul Pâinii) a fost identificat în anul 2011, odată cu lucrările de diagnostic arheologic privind lucrările autostrăzii A1, pe tronsonul Sebeș-Orăștie ${ }^{1}$. Aflată pe culoarul Orăștie ${ }^{2}$, în lunca Mureșului, zona afectată de construcția autostrăzii, prezintă în literatura de specialitate descoperiri sporadice din diferite perioade istorice ${ }^{3}$. Astfel, în anul 2012, au fost demarate lucrările de cercetare arheologică preventivă, fiind identificate şi investigate exhaustiv 300 de complexe arheologice $e^{4}$

Așezarea medievală, cercetată în anul 2012, este situată între localitățile Sebeș și Orăștie, în apropiere de actualul sat Șibot (jud. Alba), pe malul stâng al râului Cugir, în apropiere de vărsarea acestuia în râul Mureș (Pl. I).

\footnotetext{
Damian et al. 2012, 280-281. În cadrul Programului Național de Cercetare Autostrada, realizate de o echipă de arheologi de la Muzeul Național de Istorie a României (MNIR), coordonată de dr. Paul Damian.

2 Orghidan 1969, 112.

3 Sunt semnalate fragmente ceramice ce aparțin culturilor Coțofeni, Wietenberg; monede din perioada romană, precum şi ceramică din perioada medievală, vezi Moga, Ciugudean 1995, 180-181, nr. 179; Popa 2011, 692-695.

4 Samson et al. 2014, 327.
} 
Consultând vechile hărți, în special cele din secolul al XVIII ${ }^{5}$ și cele din secolele urmăroare 6 , putem vedea aspecte ale utilizării și organizărilor terenurilor în zonă, precum și localizarea unor obiective arheologice care astăzi sunt greu de reperat (Pl. II). Astfel, putem observa că traseul autostrăzii a intersectat drumuri mai vechi folosite în diferite perioade istorice.

În urma investigațiilor arheologice putem spune că este vorba de un sat medieval ce a fost distrus la sfârșitul secolului al XV-lea. Cel mai de seamă moment istoric petrecut pe actualul teritoriu al localităţii Şibot se leagă de lupta purtată împotriva turcilor în vremea regelui Matia Corvin (1458-1490). Evenimentul este cunoscut sub numele de „Bătălia de la Câmpul Pâinii” (13 octombrie 1479)7. Bătălia a avut loc pe câmpia dintre malul stâng al Mureșului și confluența acestuia cu râul Cugir, astfel satul medieval Șibot a fost prins în mijlocul câmpului de luptă ${ }^{8}$ fiind distrus. După trei secole de la bătălie, pe harta Iosefină, vatra Şibotului ne apare pe locul celei actuale, în stânga gurii de vărsare a râului Cugir în Mureş.

Descoperirile arheologice din cadrul sitului medieval de la Șibot se încadrează în categoria structurilor de habitat rural, încadrabile în trei perioade cronologice (Pl. III). Primul nivel de locuire al aşezării, din punct de vedere cronologic, este cel al secolelor XII-XIII. Este reprezentat de o locuință și gropi menajere, materialul arheologic fiind format din ceramică uzuală (oale cu decor realizat cu pieptănul în valuri, precum și căldări de lut ${ }^{9}$ ).

Cel de al doilea nivel de locuire este reprezentat de aşezarea datată în secolul al XV-lea, precum şi de nivelul de incendiere atribuit bătăliei din anul 1479. Nivelul de locuire menţionat este reprezentat prin locuinţe semiadâncite, unele dintre ele având gropi de provizii drept anexă, locuinţe cu bază de piatră, cuptoare menajere, gropi de provizii cu baza din lemn, gropi menajere. Tot în acest nivel se regăsesc cele 21 de fântâni ce sunt aliniate și mărginesc drumul aşezării ce străbate pe lungime întregul sat medieval.

Artefactele ce se regăsesc în nivelul de secol XV sunt extrem de numeroase și sunt tipice pentru o așezare rurală a vremii. Sunt identificate forme ceramice variate ${ }^{10}$ : oale, căni, carafe, ulcioare, capace, castroane, vase pentru depozitat apa, opaițe, tigăi cu trei picioare. Decorul ceramicii este divers: oalele și ulcioarele fiind decorate cu pieptănul, dar se găsesc și ulcioare din pastă albă decorate cu vopsea roșie; precum și forme ceramice smălțite, cum sunt tigăile cu trei picioare smălțuite pe interior cu glazură verde. $O$ altă categorie ceramică descoperită la Șibot este reprezentată de cahle ${ }^{11}$. Este vorba de piese variate, de la cahle placă, la cahle oală cu deschidere rectangulară, precum și cahle de coronament. Decorul de pe cahlele placă este geometric, excepție făcând două piese ce reprezintă un cavaler în armură, călare, spre stânga, iar sub picioarele calului sunt două capete de turci cu turbane ${ }^{12}$. Cahlele oală sunt simple, fără decor.

$\mathrm{O}$ altă categorie de artefacte este reprezentată de cele din metal: unelte agricole (cuțite de plug, cosoare, seceri), cuţite de uz casnic, obiecte de dulgherie (cuțitoaie, sfredele), chei, lacăt, cuțite pentru pielărie, torți de găleți, amnare, cuie şi piroane. Tot în acest nivel au fost identificate și obiecte pentru diferite îndeletniciri casnice, cum este torsul și țesutul (fusaiole, tindeche, degetar, foarfeci). În acest nivel au fost descoperiți şi o mulţime de pinteni de călărie (pinteni cu rotiță și pinteni cu spin), precum și vârfuri de săgeţi, o spadă, cuțite de luptă, scări de șa și zăbale.

Cel de al treilea nivel de locuire se referă la câteva urme de locuințe atribuite etapei post bătălie, fiind surprinse în nivelul imediat de sub stratul vegetal, acestea fiind puternic afectate de lucrările agricole.

Demersul de faţă prezintă rezultatele analizei obiectelor din os descoperite pe suprafața sitului. Artefactele analizate provin din complexele de locuire ale sitului fiind vorba de obiecte de uz casnic (într-un singur caz este vorba de plăseaua unui cuțit de luptă), un total de 23 obiecte. Din totalul artefactelor este vorba de patru pieptăni din os, cinci ace de cusut (din care unul încă la stadiul de prelucrare), trei nasturi (sau fragmente de nasturi), șase plăsele de os/corn (sunt de la cuțiele de bucătărie, unul singur fiind de la un cuțit de luptă), patru aplice (de diferite forme), și un obiect din corn ce servea drept cuier/agățătoare.

Acele de cusut descoperite în așezarea de la Şibot sunt în număr de cinci (unul dintre ele nu este finalizat, rămânând la stadiul de prelucrare), au dimensiuni asemănătoare, între 7-8 cm lungime, cu capul alungit și rotunjit (Pl. VI.

\footnotetext{
5 Harta Iosefină realizată între anii 1769-1773 se poate consulta la adresa https://mapire.eu/en/map/firstsurvey-transylvania. Pentru studiul cartografic referitor la secolul al XIX-lea a fost utilizată platforma https://mapire.eu/en/map/europe19 century-secondsurvey.

7 Hațegan 1978, 266. Referitor izvoarele documentare privind bătălia vezi Călători străini I, 1968, 480,493.

8 Pentru descrierea detaliată și desfășurarea ostilităților vezi Popa 2010, 269-306.

9 Astfel de artefacte se încadrează în așezările similare din Transilvania, cum este cea de la Bratei (vezi Ioniță 2009, 26-33).

10 Ceramica își găsește analogiile în săpăturile de la Sibiu (vezi Marcu Istrate 2007, 97).

11 O mare parte dintre cahle își găsesc analogiile în piesele descoperite la Vințu de Jos, Orăștie (vezi Marcu Istrate 2004, 249-250, 280-281).

12 Samson et al. 2016, 210, nr.cat. 43; 211, Fig. 5.a.
} 
a-e). Vârful (care nu este foarte ascuțit) și diametrul gros al acelor, ne face să credem că erau utilizate la coaserea unor materiale groase, nu de foarte bună calitate. În vederea analogiilor pentru aceste obiecte, putem spune că piese asemănătoare se regăsesc la Vinţu de $\mathrm{Jos}^{13}$, Baia ${ }^{14}$, Negoești ${ }^{15}$ și cetatea Enisala ${ }^{16}$.

În privința pieptenilor descoperiți la Șibot (toate piesele se păstrează fragmentar), putem spune că aveau utilitate casnică (trei dintre ei fiind descoperiți în locuințe, iar al patrulea într-o groapă menajeră). Sunt în număr de patru (Pl. V. a-d), toți făcând parte din același tip. Sunt confecționați din oase lungi (metapod de vită). Forma lor este după cea a osului din care sunt confecționate, la unul din capete fiind dinții lungi și foarte deși (între ei sunt spații de $0,01 \mathrm{~cm}$ ). Lățimea lor variază între 3 și $4 \mathrm{~cm}$, iar lungimea păstrată este de maxim $12 \mathrm{~cm}$. În partea superioară unul dintre ei prezintă la fiecare colț câte o perforație circulară, ce servea la agățarea pieptenului. În privința utilității acestui tip de piepteni au fost emise mai multe teorii: au fost socotite obiecte utilizate la războiul de țesut vertical sau pieptăni pentru decorat ceramica, și nu în ultimul rând piepteni pentru păr ${ }^{17}$. În cazul celor de la Şibot, suntem de părere că au fost utilizați la pieptănat sau la prins părul. Acest tip de piepteni se regăsesc la Oradea ${ }^{18}$, precum și în Europa, în spațiul german ${ }^{19}$.

În așezarea medievală de la Șibot a fost descoperită o agățătoare din corn (Pl. VII. d). Este vorba de un corn de cervideu, găurit la unul din capete, printr-o perforație circulară, iar la capătul ascuțit a fost șlefuit. Obiectul a fost descoperit într-una din fântânile din așezare, fiind utilizat cel mai probabil drept agățătoare pentru una din carafele de pe marginea fântânii, întrucât partea superioară a fântânii era din lemn, cel mai probabil pe marginea acestuia erau agățate vase pentru băut (carafe sau căni).

Plăsele de la cuțite de uz casnic sunt în număr de cinci (Pl. VIII. a-e), fiind realizate din corn. Toate piesele sunt fragmentare și prezintă perforații circulare pentru nituri. Lățimea lor variază între 1 și $1,8 \mathrm{~cm}$, iar lungimea păstrată variază între 3 și $6,5 \mathrm{~cm}$ Sunt de mai multe tipuri: plăsele plate înspre lamă și semicirculare spre exterior, rectangulare în secțiune (paralepipedice) și semicirculare în secțiune. Sunt tăiate drept sau oblic în extremitatea liberă. Nu se păstrează nici o piesă care să aibă extremitatea dispre lamă. Analogiile pentru aceste tipuri de plăsele se regăsesc în spațiul românesc la Oradea, Vințu de Jos, Frumușeni (jud. Arad), Cristuru Secuiesc ${ }^{20}$.

Nasturii nu sunt foarte numeroși, fiind descoperiți doar trei (Pl. VII. a-d), dintre care doi se păstrează fragmentar (Pl. VII. b-c). Aceste două fragmente sunt subțiiri, asemănându-se cu capetele acelor de cusut, însă mai ascuțite, cu vărful rotunjit. La celălalt capăt al pieselor se păstrează orificiul circular din mijlocul piesei. Cel de al treilea nasture (Pl. VII. a) este de formă triunghiulară, prezintă două orificii circulare, este rectangular în secțiune și are un decor cu cercuri concentrice (ochiuri).

În aşezarea medievală de la Şibot au fost descoperite mai multe cuțite de luptă sau fragmente din acestea ${ }^{21}$. Se păstrează o plăsea din corn (Pl. VIII. f); aceasta a fost decupată din bucăţi mai mari de corn, apoi şlefuită, perforată şi fixată pe mâner. Capătul mânerului este simplu, adică fără o aplică. Perforaţiile pentru nituri sunt în număr de nouă şi sunt dispuse în forma literei "Y"22.

Numărul de aplice este de patru (Pl. IX. a-d). Două dintre ele sunt din os (Pl. IX. a și d). De formă circulară, cea mai mică prezintă patru picioare de prindere (Pl. IX. d) și cel mai probabil era prină pe un obiect de bronz. Cea de-a doua aplică de os (Pl. IX. a), are diametrul mai mare, de $5 \mathrm{~cm}$, prezintă pe margine patru crestături în formă de $M$, iar în centru o perforație circulară; piesa este foarte subțire, cu o grosime de $0,2 \mathrm{~cm}$. Celelate două aplice (Pl. IX b și c) sunt din corn de cerb, fiind curbate și cu perforații circulare pentru nituri. Una dintre ele prezintă pe toată lungimea ei un decor geometric, incizat (Pl. IX. c). Pentru aceasta avem piese asemănătoare descoperite la Cristuru Secuiesc ${ }^{23}$.

Determinările de ordin faunistic ${ }^{24}$ ne dezvăluie că din totalul de 23 de piese, toate aparțin mamiferelor, în general de talie mare sau medie. Oasele prelucrate sunt metapod, scapula, diafiza sau cornul. În cazul animalelor domestice, acestea sunt bos taurus, ovicaprine, sau animale de talie mare; lista este completată de animalele sălbatice, ca

13 Rusu, Mărginean 2005,120, 154, P1. I.1.

14 Neamțu, Neamțu, Cheptea 1980, 203, Fig. 51/4.

Popovici 2002, 41, Fig. 6/3.

Dragomir 1972-1973, 47, Fig. 19/5.

Rusu, Mărginean 2005, 121.

Rusu et al. 2002, 116; Rusu, Mărginean 2005, 127.

Rusu, Mărginean 2005, 121.

Rusu, Mărginean 2005, 122.

Oța, Samson 2016, 195-196.

Oța, Samson 2016, 196.

Rusu, Mărginean 2005, 132, 158, Pl. XIV/11-23.

24 Determinările de ordin faunistic au fost făcute către dr. Adrian Bălășescu (Institutul de Arheologie Vasile Pârvan, București) căruia îi mulțumim pe această cale. 
cervus elaphus. Cornul de cerb este utilizat pentru plăsele de cuțit, dar și în cazul obiectului ce a fost utilizat drept cuier/agățătoare. Una dintre plăsele este fabricată dintr-o diafiză de mamifer domestic. Pentru piepteni sunt utilizate metapoade ce au aparținut animalelor mari (bos taurus). În cazul acelor de cusut putem spune că au fost utilizate diafize de mamifere mari, iar obiectul circular (Pl. IX. a) cu o perforație în centru aparține unei scapule de ovicaprină.

În concluzie, putem spune că, satul medieval cercetat în anul 2012 în raza actualului sat Șibot, a condus la investigarea completă a zonelor de nord, vest și est ale sitului arheologic Şibot (Cânepişte). Întinderea sitului este cu mult mai mare decât zona cercetată, respectiv la sud-est de traseul autostrăzii, între traseul A1 și actualul traseu al lui DN7, precum și la sud de acesta. Acest fapt este evident și avem o serie de indicii semnificative despre existența unei necropole aferente aşezării medievale. Materialele arheologice descoperite se încadrează în două orizonturi de locuire: primul este databil în secolele XII-XIII, iar cel de al doilea nivel de locuire este cel mai consistent, reprezentat de complexele datate în secolul al XV-lea. Aici regăsim fragmente ceramice, cahle, obiecte din bronz, obiecte din fier, obiecte din os/corn. Artefactele din os/corn provin din complexe închise, locuințe, fântâni sau gropi menajere, fiind vorba de obiecte de uz comun (cu o singură excepție). Oasele utilizate la prelucrare provin de la animale de talie mare (bos taurus sau ovicaprine). În cazul obiectelor de luptă a fost utilizat cornul de cerb.

\section{Catalog ${ }^{25}$ :}

1. Pieptăn, SA2, cpl. 220; nr. inv. 378212, $\mathrm{Lp}=9,02 \mathrm{~cm} ; 1=3,5 \mathrm{~cm} ; \mathrm{Gr}=0,5$; metapod bos taurus, forma este rectangulară, se păstrează fragmentar, cei opt dinți sunt lungi (se păstrează pe o lungime de $4,9 \mathrm{~cm}$ ) și foarte deși, între ei este o grosime de $0,1 \mathrm{~cm}$. În partea superioară sunt două perforații circulare ce folosesc la agățarea pieptenului; Pl. V/a.

2. Pieptăn, SA4, cpl. 115; nr. inv. 378213, $\mathrm{Lp}=5,5 \mathrm{~cm} ; 1=3,7 \mathrm{~cm} ; \mathrm{Gr}=0,7 \mathrm{~cm}$; metapod bos taurus, forma este rectangulară, se păstrează fragmentar, se păstrează fragmentar, cei șapte dinţi sunt (se păstrează pe o lungime de $1,5 \mathrm{~cm}$ ) foarte deși, între ei este o grosime de $0,1 \mathrm{~cm} ; \mathrm{Pl}$. V/d.

3. Pieptăn, SA4, cpl. 103A; nr. inv. 378214, Lp =11,2 cm; $1=4 \mathrm{~cm} ; \mathrm{Gr}=0,6 \mathrm{~cm}$; metapod bos taurus, forma este rectangulară, se păstrează fragmentar, cei doisprezece dinți sunt lungi (se păstrează pe o lungime de $6,8 \mathrm{~cm}$ ) și foarte deși, între ei este o grosime de $0,1 \mathrm{~cm} ; \mathrm{Pl}$. V/b.

4. Pieptăn; SA2, cpl. 241; nr. inv. 378215, Lp = 5,6 cm; $1=3,4 \mathrm{~cm}$; $\mathrm{Gr}=0,7 \mathrm{~cm}$; metapod bos taurus, forma este rectangulară, se păstrează fragmentar, cei opt dinți sunt lungi (se păstrează pe o lungime de $0,7 \mathrm{~cm}$ ) și foarte deși, între ei este o grosime de $0,1 \mathrm{~cm} ; \mathrm{Pl}$. V/c.

5. Ac de cusut; SA4, cpl 67B; nr. inv. 378216, os, diafiză, mamifer de talie medie; $\mathrm{L}=7 \mathrm{~cm} ; 1=0,5 \mathrm{~cm}, \mathrm{Gr}=0,3$ $\mathrm{cm} ; \varnothing$ urechii $=0,2 \mathrm{~cm}$; forma este alungită, capul rotunjit; Pl. VI/a.

6. Ac de cusut; SA4, cpl. 137; nr. inv. 378217, os, diafiză, mamifer de talie medie; $\mathrm{L}=8,4 \mathrm{~cm} ; 1=0,8 \mathrm{~cm}, \mathrm{Gr}=0,3$ $\mathrm{cm}$; Ø urechii $=0,3 \mathrm{~cm}$; forma este alungită, capul rotunjit; Pl. VI/b.

7. Ac de cusut; SA4; cpl. 199; $\mathrm{nr}$. inv. 378218, os, diafiză, mamifer de talie medie; $\mathrm{L}=7,8 \mathrm{~cm}, 1=0,5 \mathrm{~cm} ; \mathrm{Gr}=0,3$ $\mathrm{cm}$; Ø urechii $=0,2 \mathrm{~cm}$; forma este alungită, capul rotunjit ${ }^{26} ; \mathrm{Pl} . \mathrm{VI} / \mathrm{c}$.

8. Ac de cusut; SA1; cpl. 47, nr. inv. 378219 , os, diafiză, mamifer de talie medie; $\mathrm{L}=6,3 \mathrm{~cm}, 1=0,4 \mathrm{~cm} ; \mathrm{Gr}=0,2$ $\mathrm{cm}$; Ø urechii $=0,8 \times 0,2 \mathrm{~cm}$; forma este alungită, capul rotunjit; Pl. VI/d.

9. Ac de cusut; SA4, cpl. 135; nr. inv. 378220, os, diafiză, mamifer de talie medie; $\mathrm{L}=9,6 \mathrm{~cm} ; 1=0,7 \mathrm{~cm} ; \mathrm{Gr}=0,3$ $\mathrm{cm}$; forma este alungită, capul rotunjit; acul nu a fost finalizat, îi lipsește perforația urechii; Pl. VI/e.

10. Agățătoare; SA2, Cpl. 37; nr. inv. 378221, L = $20 \mathrm{~cm}, \varnothing$ maxim $=2 \mathrm{~cm}$; corn, cervus elaphus, vârful este şlefuit, în capătul celălalt are un orificiu cu $\varnothing=1 \mathrm{~cm}^{27} ; \mathrm{Pl}$. VII/d.

11. Plăsea, cuțit de uz casnic, SA2, Cpl. 37; nr. inv. 378222, os, diafiză, mamifer de talie mare; L = $5 \mathrm{~cm}, 1=0,7$ $\mathrm{cm}, \mathrm{Gr}=0,2 \mathrm{~cm}$; fragment, rectangulară în secţiune, se păstrează capătul dinspre exterior, rotunjit; are două orificii de prindere pe cuţit ${ }^{28} ; \mathrm{Pl}$. VIII/a.

\footnotetext{
25 Vocile din catalog sunt prezente după următoarele criterii și în această ordine: tip obiect, context arheologic, număr de inventar, dimensiuni, descriere material, descriere obiect, decor obiect (după caz), bibliografie/analogii. Au fost folosite următoarele abrevieri: D - diametru, H - inălțime, p - păstrată, L - lungime, 1 - lăţime, Gr - grosime, $\varnothing$ = diametru.

26 Samson et al. 2014, 331, P1. XV/4.

27 Samson 2015, 230, 242, Fig. 6/ș.

28 Samson 2015, 230, 242, Fig. 6/s.
} 
12. Plăsea, cuțit de uz casnic; SA4, cpl. 113; nr. inv. 378223, corticală de corn, cervus elaphus; Lp = 5 cm; $1=1$ cm; Gr =0,4 cm; fragment, semicirculară în secţiune, se păstrează capătul dinspre exterior, rotunjit; are trei orificii de prindere pe cuţit; Pl. VIII/b.

13. Plăsea, cuțit de uz casnic; SA4; cpl. 64; nr. inv. 378224; corticală de corn, cervus elaphus; Lp = 3,2 cm; $1=$ $1,3 \mathrm{~cm} ; \mathrm{Gr}=0,2 \mathrm{~cm}$; fragment, semicirculară în secţiune, se păstrează capătul dinspre exterior, rotunjit; are două orificii de prindere pe cuţit; Pl. VIII/c.

14. Plăsea, cuțit de uz casnic; SA6; cpl. 175; nr. inv. 378225; corticală de corn, cervus elaphus; Lp =6,1 cm; $1=1,1$ $\mathrm{cm}, \mathrm{Gr}=0,2 \mathrm{~cm}$, fragment, semicirculară în secţiune, are două orificii de prindere pe cuţit; P1. VIII/d.

15. Plăsea, cuțit de uz casnic; SA4, cpl. 132; nr. inv. 378226; corn, cervus elaphus; Lp =6,5 cm, $1=1,8 \mathrm{~cm}$; gr = $0,3 \mathrm{~cm}$; fragment, semicirculară în secțiune, se păstrează capătul dinspre exterior, drept; are trei orificii de prindere pe cuţit, trei nituri de fier, pe revers se păstrează fragmente din mânerul cuţitului; Pl. VIII/e.

16. Nasture; SA1, cpl. 19; nr. inv. $378227 ; \mathrm{L}=3,9 \mathrm{~cm} ; 1=2,5 \mathrm{~cm} ; \mathrm{Gr}=0,4 \mathrm{~cm} ; \varnothing$ orificii $=0,3 \mathrm{~cm}$; formă triunghiulară, rectangular în secțiune, prezintă două orificii circularepentru prindere; decorul este compus din cinci ochi incizați pe avers, iar pe margine din linii oblice incizate; Pl. VII/a.

17. Nasture; SA2, cpl. 31; nr. inv. 378228; os, diafiză, mamifer de talie medie; $\mathrm{Lp}=1,9 \mathrm{~cm}, 1=0,6 \mathrm{~cm} ; \mathrm{Gr}=0,2$ $\mathrm{cm}$; $\varnothing$ orificiu = 0,2 cm; fragmentar, forma alungită, capul rotunjit; Pl. VII/b.

18. Nasture; SA2, cpl. 199; nr. inv. 378229; os, diafiză, mamifer de talie medie; Lp =3,8 cm; $1=0,5$ cm; Gr =0,3 $\mathrm{cm} ; \varnothing$ orificiu $=0,2 \mathrm{~cm}$; fragmentar, forma alungită, capul rotunjit ${ }^{29} ; \mathrm{Pl}$. II/c.

19. Plăsea, cuțit de luptă, SA4, cpl. 67; nr. inv. 378230; corticală de corn, cervus elaphus L=113 mm, l=27 mm, grosime $=9 \mathrm{~mm}$. L nitului $=20 \mathrm{~mm}$, grosime nit $=5 \mathrm{~mm}$; fragmentar, semicircular în secțiune; se păstrează un fragment din gardă, perforaţiile pentru nituri sunt în număr de nouă şi sunt dispuse în forma literei "Y"30; Pl. VIII/f. 20. Aplică; SA3, cpl. 195; nr. inv. 378232; Ø =1,3 cm; Gr =0,2 cm; Ø orificiu =0,2 cm; de formă circulară, are un orificiu central circular, prezintă patru picioruşe pentru prindere; pe revers sunt urme de oxid de bronz; Pl. IX/a. 21. Aplică; SA2, cpl. 249; Nr. inv. 378231; scapulă, mamifer de talie medie (ovicaprină sau suin); Ø = 5 cm; Gr $=0,2 \mathrm{~cm} ; \varnothing$ orificiu $=0,5 \mathrm{~cm}$; de formă circulară, are un orificiu central circular, pe margine sunt patru crestături sub formă de $M ; \mathrm{Pl}$. IX/d.

22. Aplică; SA4; cpl. 129; nr. inv. 378233; corticală de corn, cervus elaphus; $\mathrm{Lp}=11,7 \mathrm{~cm}, 1=1,4 \mathrm{~cm}, \mathrm{Gr}=0,3$ cm; fragmentară, semicirculară în secțiune, se păstrează capătul dinspre exterior, tăiat drept, are un orificiu circular pentru prinderea unui nit, în extremitatea capătului se păstrează un nit din os; decorul este compus din patru linii longitudinale paralele incizate, iar în interiorul acestora sunt incizate șiruri de $M$-uri afrontate; $\mathrm{Pl}$. IX/c.

23. Aplică; SA3; cpl. 201; nr. inv. 378234; corticală de corn, cervus elaphus; $\mathrm{Lp}=9 \mathrm{~cm}, 1=1,5 \mathrm{~cm}, \mathrm{Gr}=0,3 \mathrm{~cm}$; fragmentară, semicirculară în secțiune, se păstrează capătul dinspre exterior, tăiat drept, are două orificii circular pentru prindere, în unul dintre orificii se păstrează un nit din os; pe avers sunt umrme de ardere secundară; Pl. IX/b. 


\section{BIBLIOGRAFIE}

Holban M. (coord), Alexandrescu-Dersca Bulgaru M. M., Cernovodeanu P. și Totoiu I. 1968. Călători străini despre ţările române, I, Bucureşti: Editura Științifică.

Damian, P., Bocan, I., Dumitraşcu, E., Ene, D. L., Ene, S. E. I. şi Streinu, M. 2012. Raport arheologic de diagnostic. Autostrada Orăş̦tie-Sibiu, Lot 1 (Orăștie-Sebeș), km 00+000-24+110, jud. Hunedoara, Alba. Cronica Cercetărilor Arheologice din România, Campania 2011: 280-281.

Dragomir, I. T. 1972-1973. Cetatea medievală de la Enisala. Unelte, arme și obiecte de podoabă. Danubius 6-7: $29-48$.

Haţegan, I. 2009. Bătălia de pe Câmpul Pâinii (13 Octombrie 1479). Apulum XVI: 261-274.

Ioniță, A. 2009. Aşezarea din secolele XII-XIII de la Bratei. Alba Iulia: Editura Altip.

Marcu Istrate, D. 2004. Cahle din Transilvania şi Banat de la începuturi până la 1700. Cluj-Napoca: Accent.

Marcu Istrate, D. 2007. Sibiu. Piaţa Huet. Monografie arheologică, I. Alba Iulia: Editura Altip.

Moga V., Ciugudean H. 1995. Repertoriul arheologic al judeţului Alba, Alba Iulia: Muzeul Naţional al Unirii Alba Iulia.

Neamțu, E., Neamțu, V. și Cheptea, S. 1980. Orașul medieval Baia în secolele XIV-XVII, Iași: Junimea.

Orghidan, N. 1969. Văile transversale din România. Studiu geomorfologic, Bucureşti: Editura Academiei Republicii Socialiste România.

Oța, S. și Samson, A. 2016. Several observations on the Meddieval battle knives found on the teritory of Romania (the MNIR Collection). Ziridava 30:189-210.

Popa, C. I. 2010. Lupta de pe Câmpul Pâinii (13 Octombrie 1479). De la universalitatea lied-ului medieval la recuperarea eroilor naționali. Terra Sebvs. Acta Mvsei Sabesiensis 2: 269-306.

Popa, C. I. 2011. Valea Cugirului din preistorie până în zorii epocii moderne. Monumenta Archaeologica et Historica. Cluj-Napoca: Editura Mega.

Popovici, R. 2002. Negoești, un sat din zona Neamț în secolele XIV-XVII. Arheologia Medievală V: 27-45.

Rusu, A. A. (coord.), Marta, D., Lupescu, R., Zoltán, S., András, F., Mureșan, O., Bejenaru, L., Benea, M., Velter, A. M. și Oberländer-Târnoveanu, E. 2002. Cetatea Oradea. Monografie Arheologică. I. Zona palatului episcopal, Oradea: Editura Muzeului Țării Crișului.

Rusu, A. A., Mărginean, Fl. 2005. Prelucrarea osului și cornului în Transilvania medievală (început de abordare tematică). Arheologia Medievală V:113-158.

Samson, A. 2015. Fântânile din așezarea medievală de la Șibot, jud. Alba. Materiale și Cercetări Arheologice (serie nouă) XI: 227-256.

Samson, A., Vasile, M., Ene, I., Ene, S. E. I., Streinu, M., Bodó, C. și Băeștean, G. 2014. Situl arheologic medieval de la Şibot (Cânepiște), jud. Alba. Raport preliminar asupra cercetărilor arheologice preventive (campania 2012). Cercetări Argeologice XXI: 327-362.

Samson, A., Bălăşescu, A. și Radu, V. 2016. O locuință descoperită în situl medieval de la Şibot (jud. Alba). Analiza arheologică și arheozoologică. Materiale și Cercetări Arheologice (serie nouă) XII: 205-230. 


\section{LIST OF PLATES}

Plate I. The archeological site on the map of Romania.

Plate II. Josephine map (1769-1773).

Plate III. a) General layout of the site's location; b) General plan per types of complexes.

Plate IV. Distribution of bone artefacts in the site.

Plate V. Bone combs. a) Catalogue no. 1; b) Catalogue no. 3; c) Catalogue no. 4; d) Catalogue no. 2.

Plate VI. Bone sewing needles. a) Catalogue no. 5; b) Catalogue no. 6; c) catalogue no. 7; d) catalogue no. 8; e) catalogue no. 9 .

Plate VII. Bone buttons: a) catalogue no. 16; b) catalogue no. 17; c) catalogue no. 18; d) horn hanger, catalogue no. 10 .

Plate VIII. Handles of kitchen knives; a) catalogue no. 11; b) catalogue no. 12; c) catalogue no. 13; d) catalogue no. 14; e) catalogue no. 15; f) handle of battle knife, catalogue no. 19.

Plate IX. Bone plaques. a) Catalogue no. 20; b) catalogue no. 23; c) catalogue no. 22; d) catalogue no. 21.

ANDRA SAMSON

Muzeul Național de Istorie a României andrasamson@gmail.com 


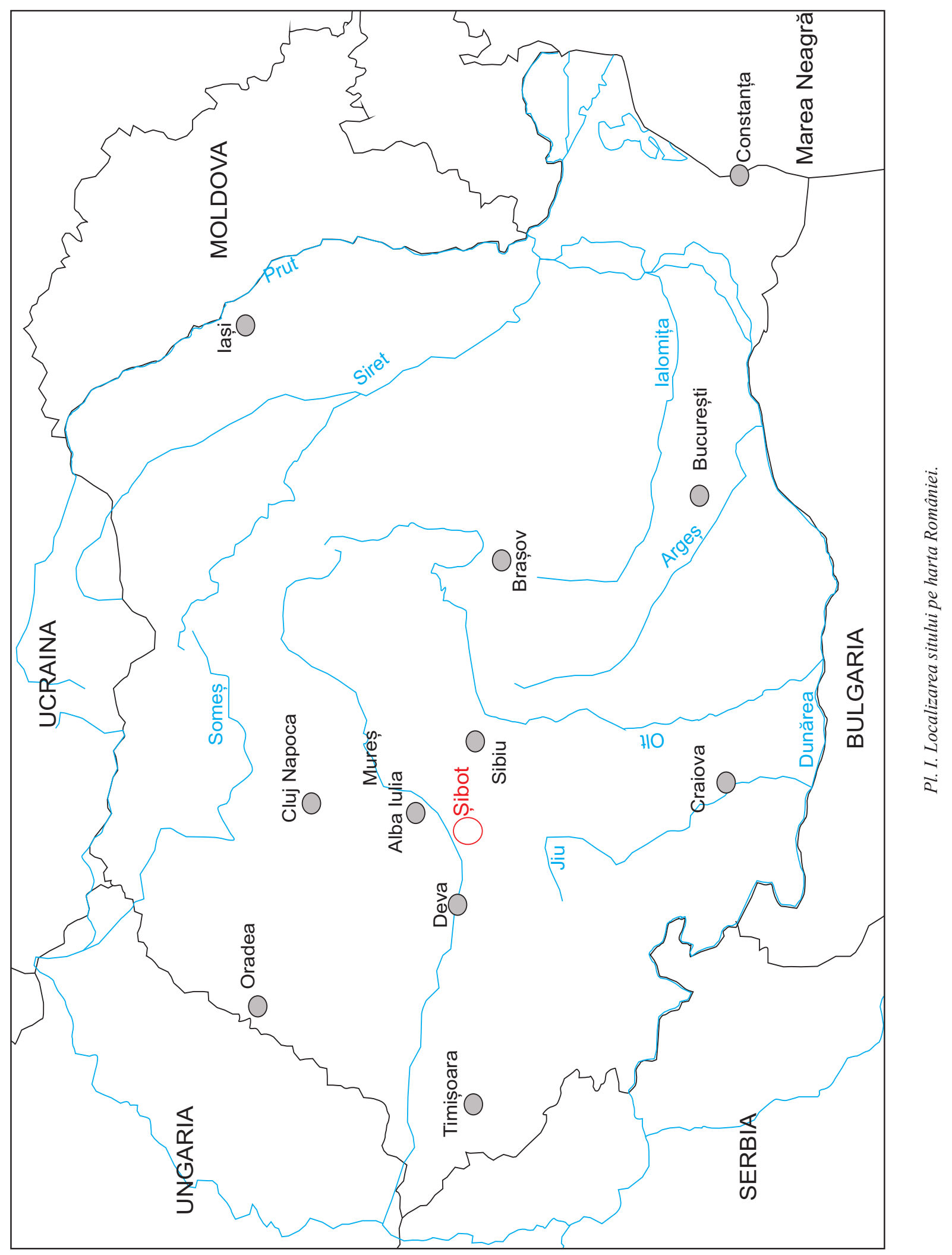




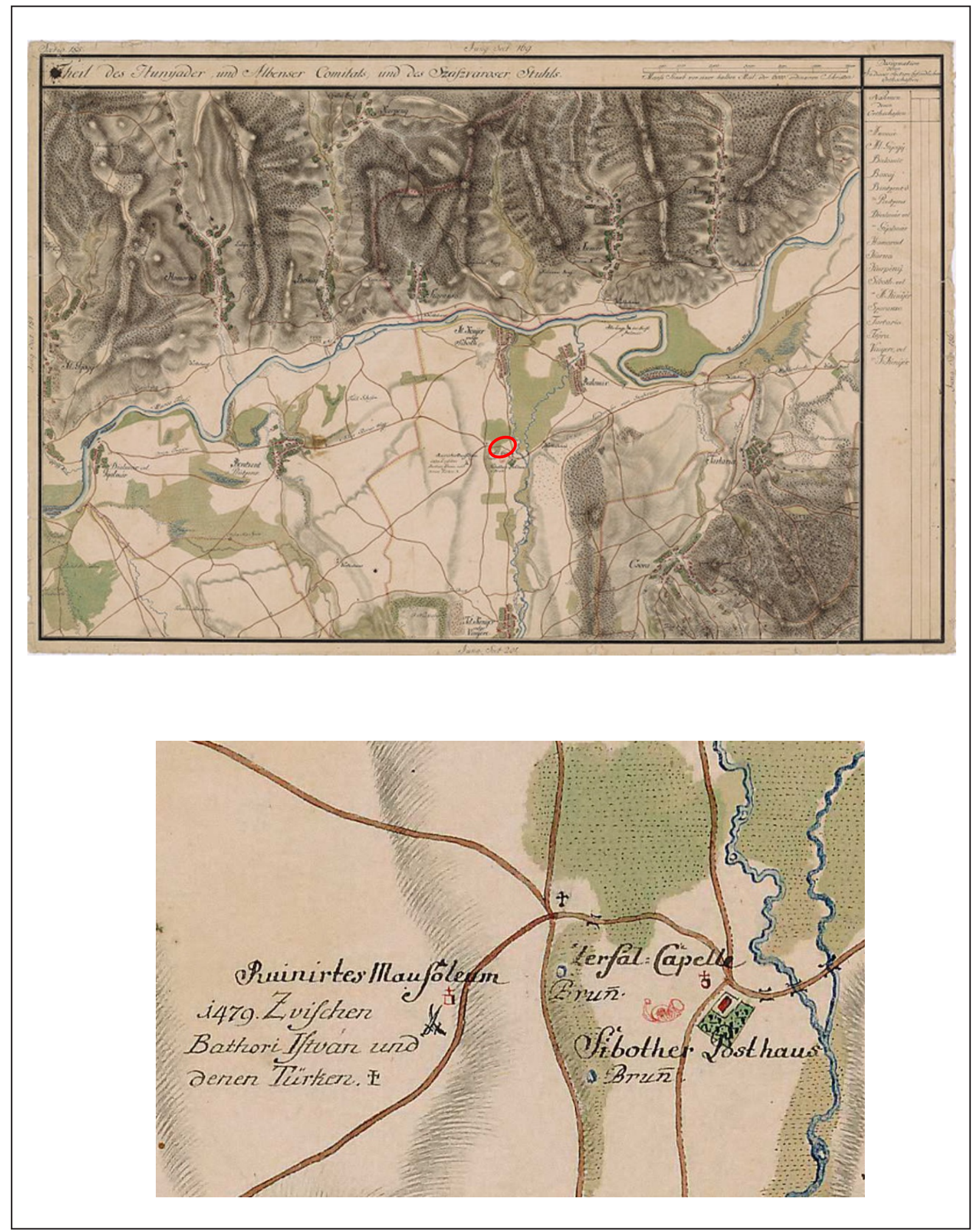

Pl. II. Harta iosefină (1769-1773). 

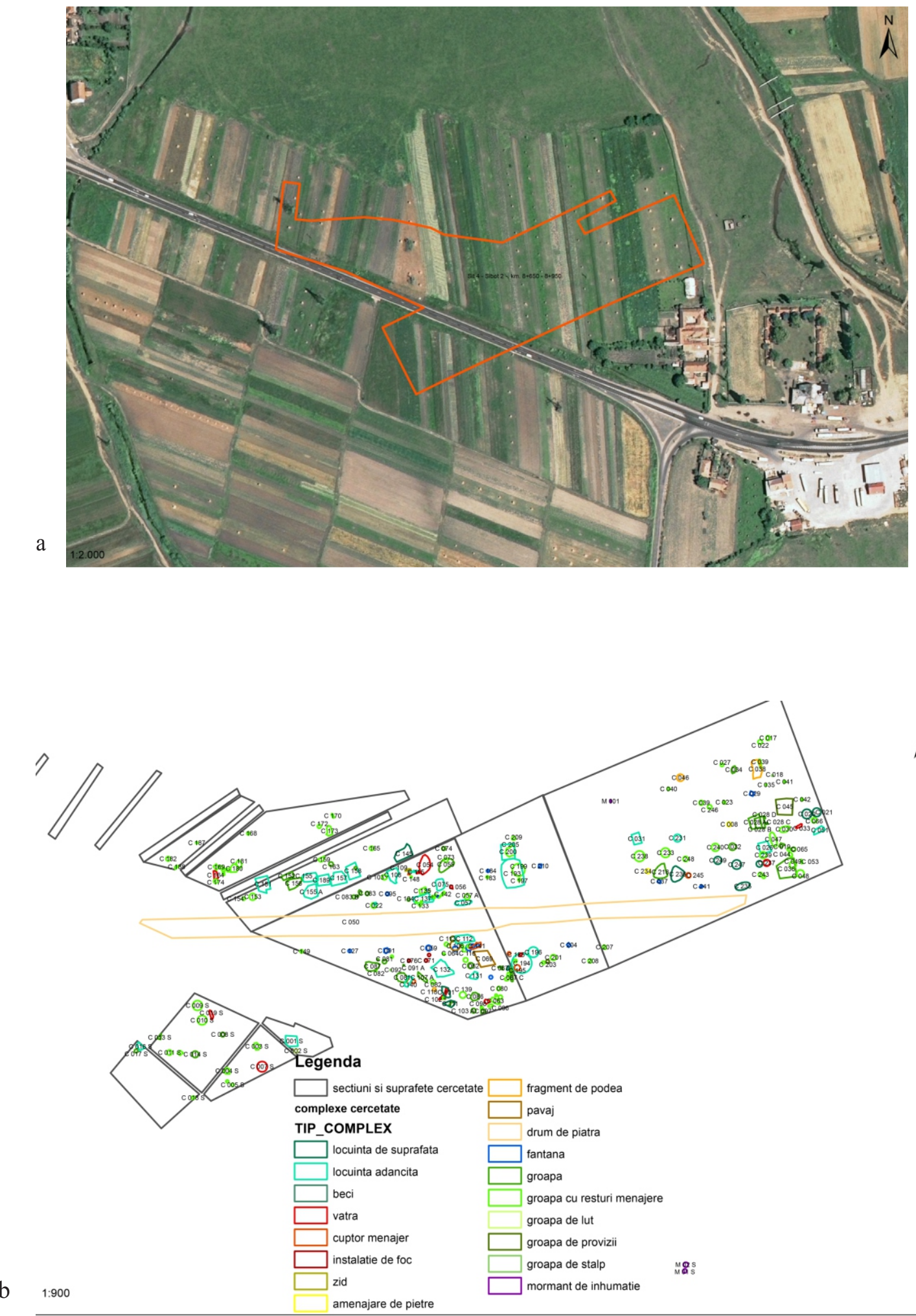

$\Lambda$

Pl. III. a) Planul general al amplasării sitului; b) Planul general pe tipuri de complexe. 


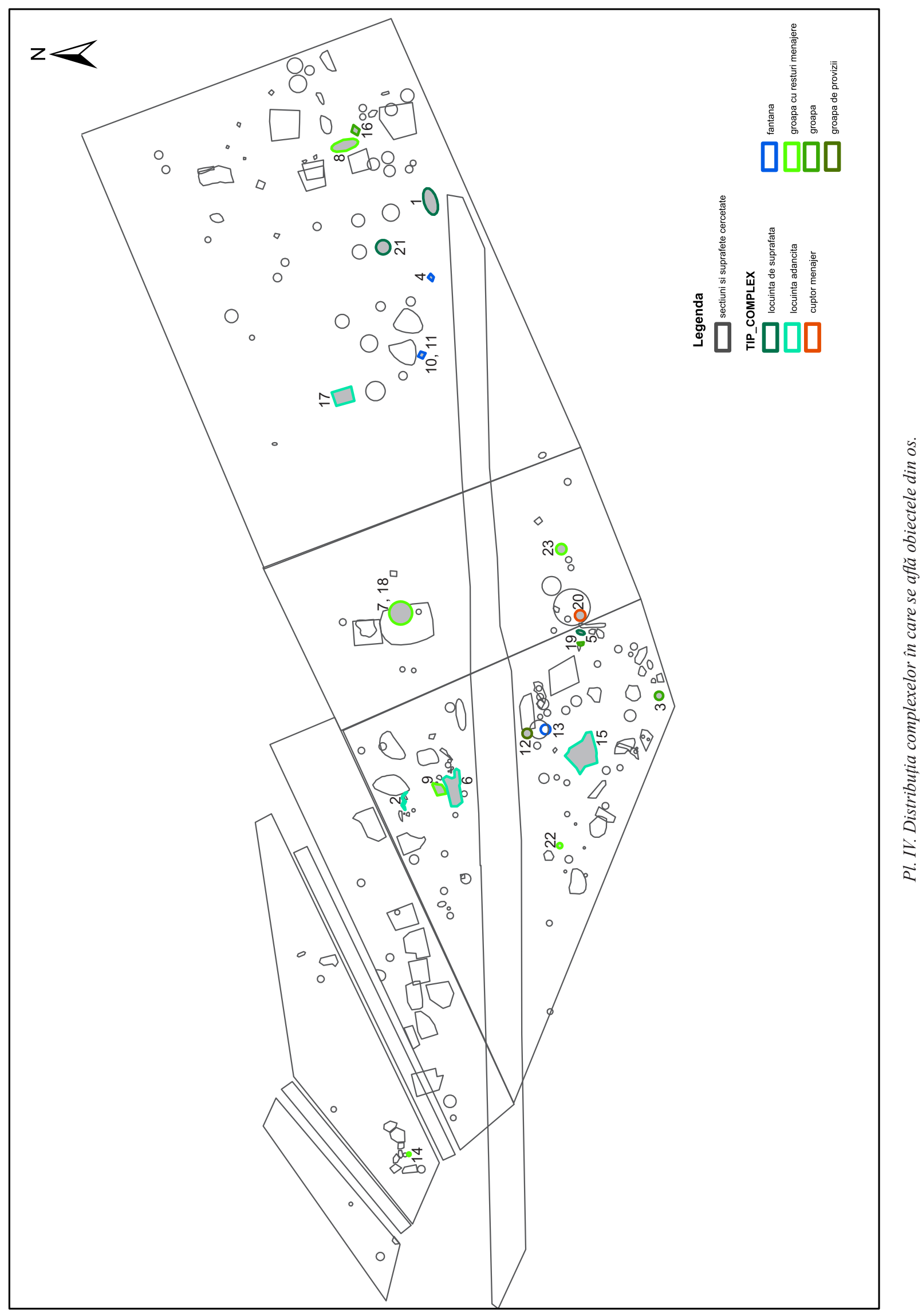


a

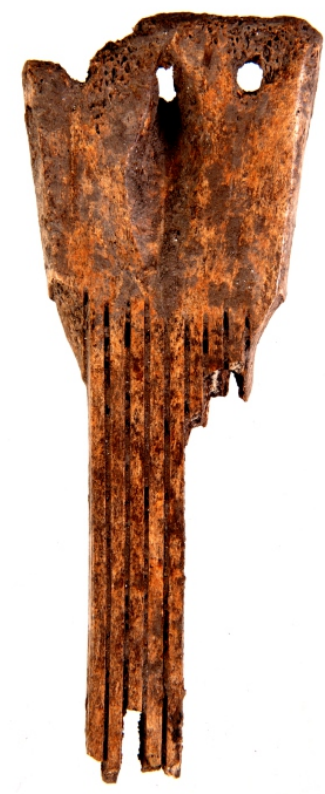

c

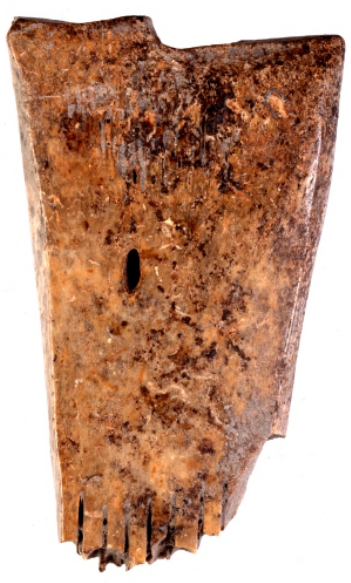

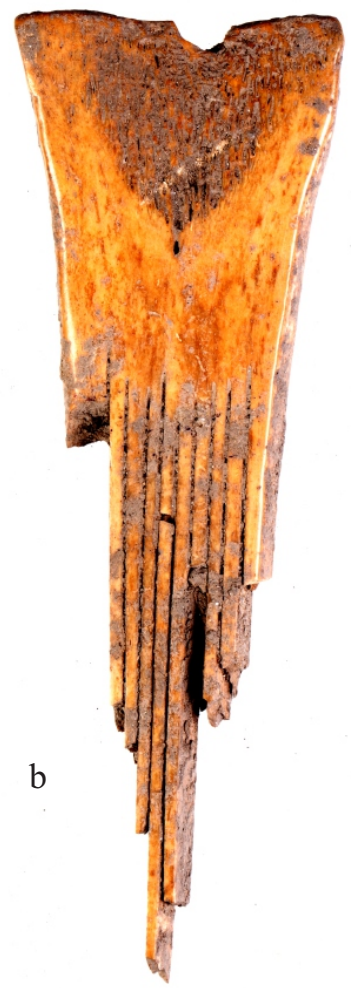

d
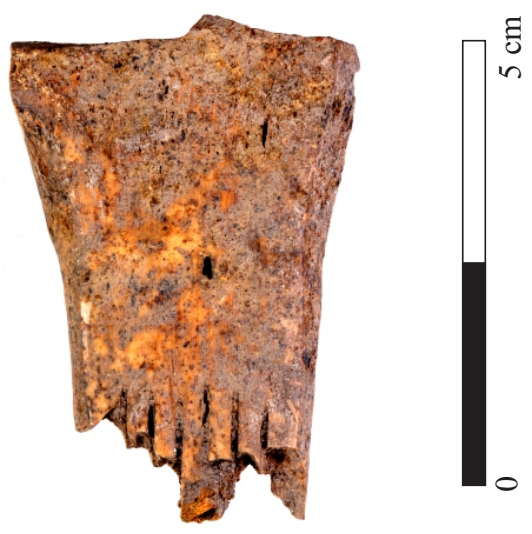

Pl. V. Pieptăni din os. a) nr.cat. 1; b) nr. cat. 3; c) nr. cat. 4; d) nr. cat. 2. 

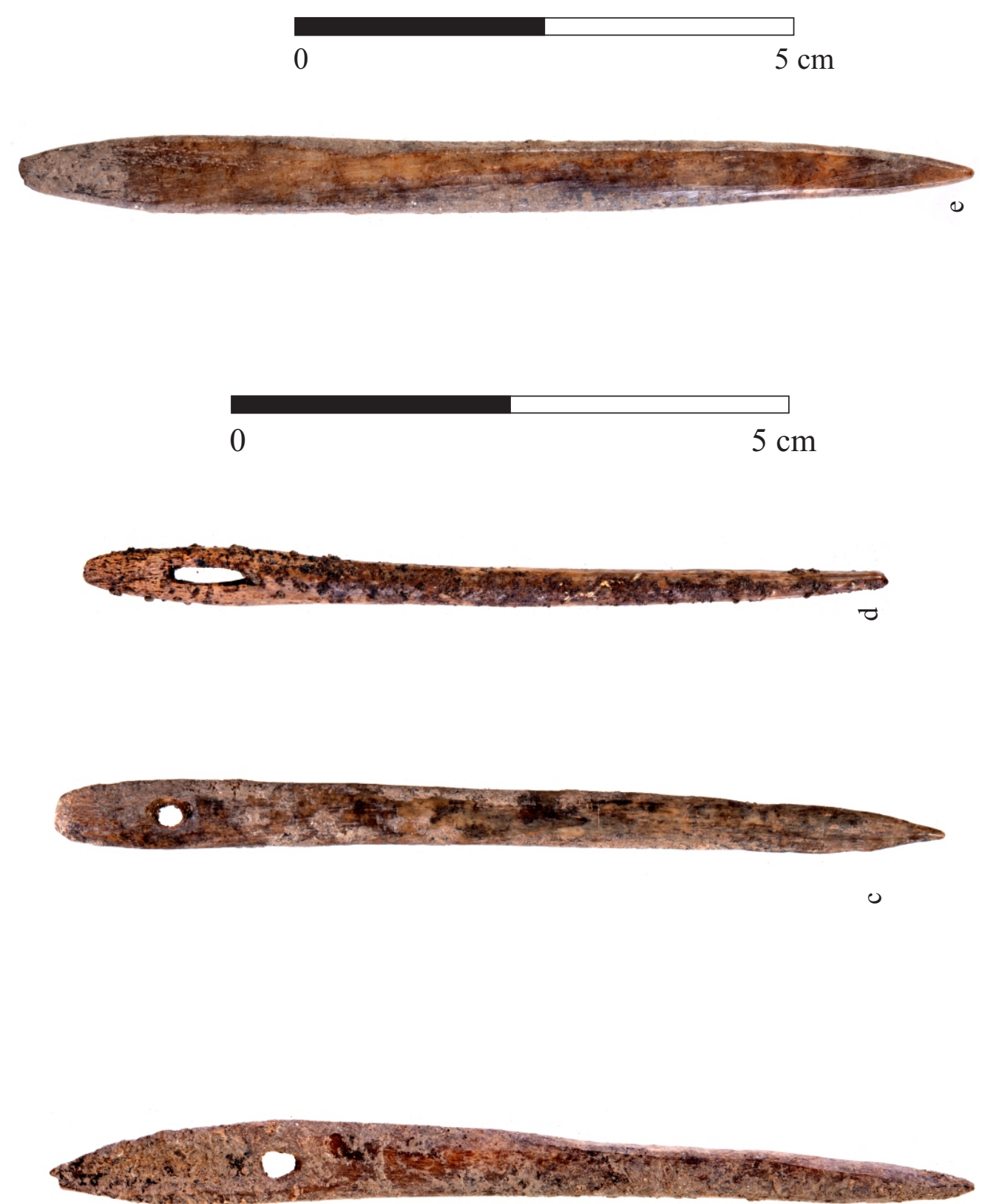

○ 


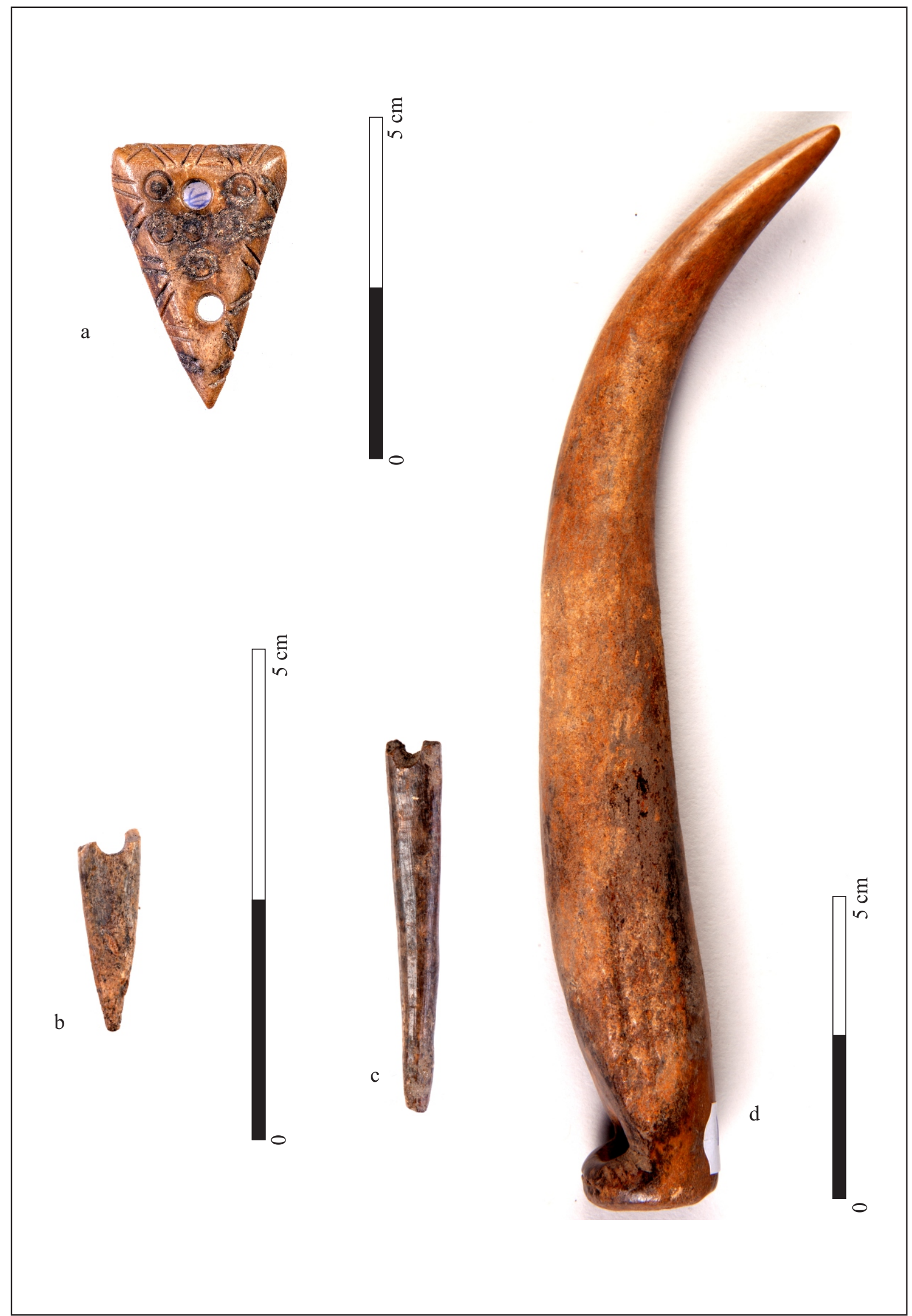

Pl. VII. Nasturi din os: a) nr. cat. 16; b) nr. cat. 17; c) nr. cat. 18; d) agățătoare din corn, nr. cat. 10. 


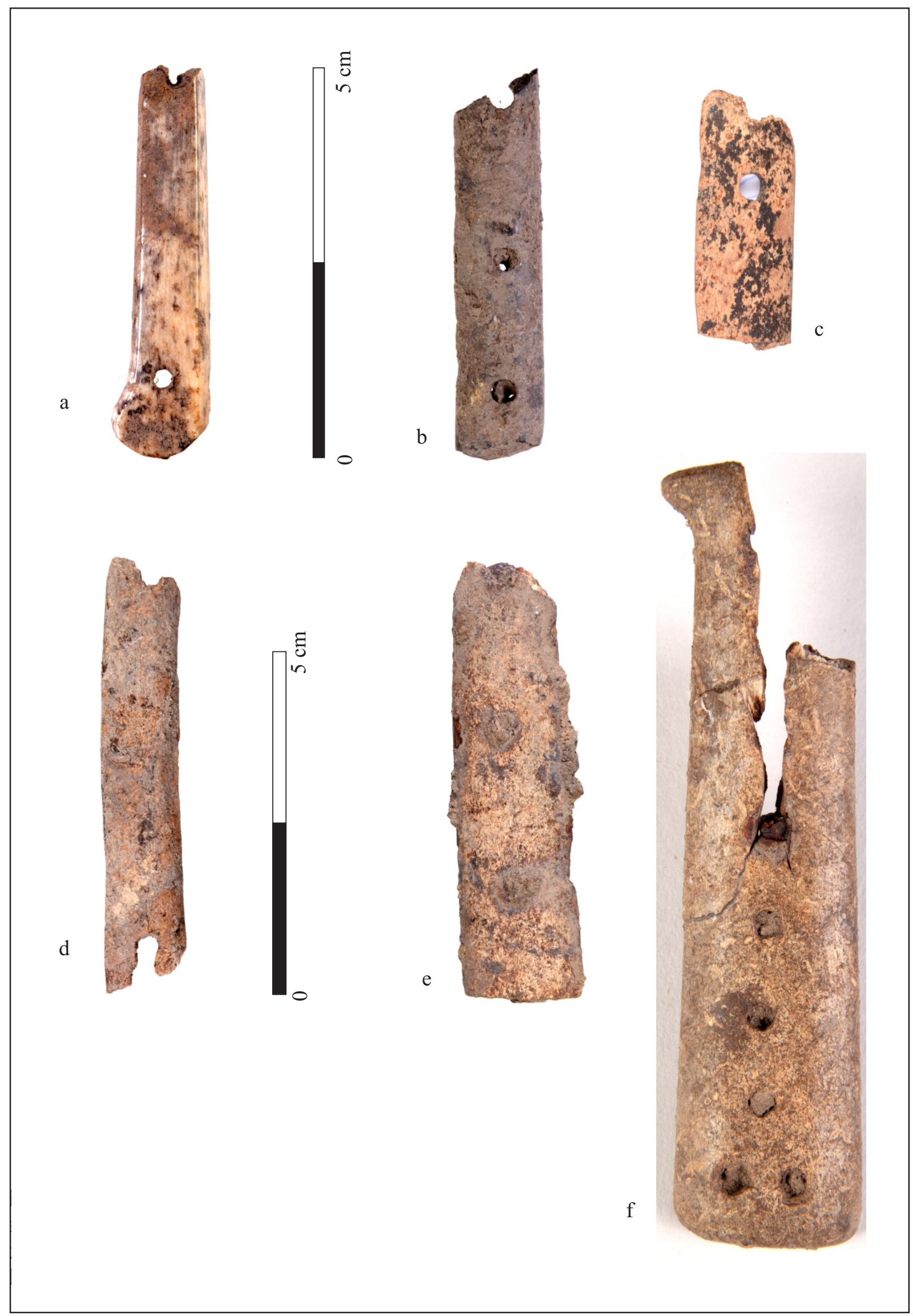

Pl. VIII. Plăsele de la cuțitele de bucătărie; a) nr. cat. 11; b) nr. cat. 12; c); nr. cat. 13; d) nr. cat. 14; e) nr. cat.15; f) plăsea de la un cuțit de luptă, nr. cat. 19. 


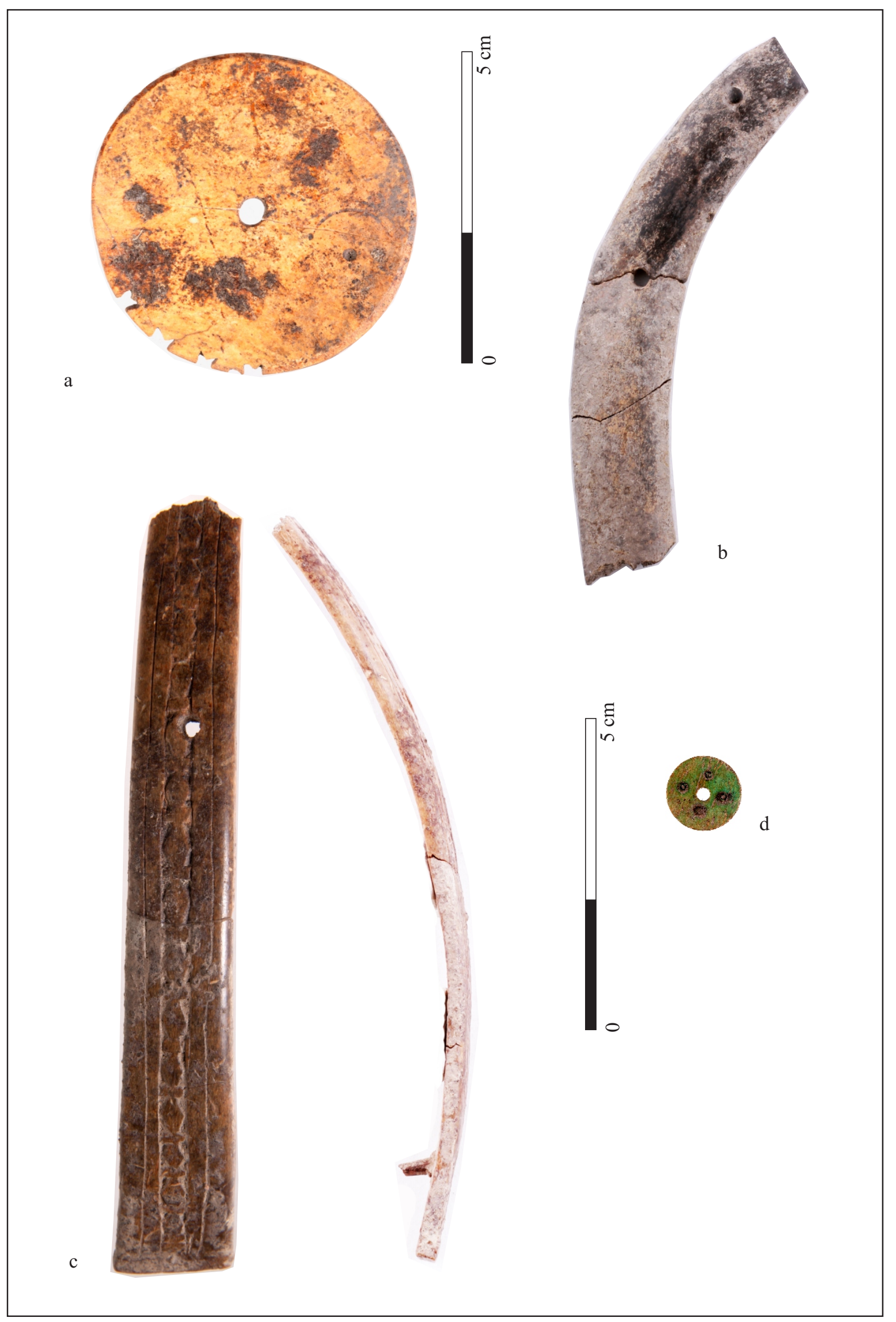

Pl. IX. Aplice de os. a) nr. cat. 20; b) nr. cat. 23; c) nr. cat. 22; d) nr cat. 21 . 